\title{
Checklist and contribution to the knowledge of the odonatofauna of Paraíba state, Brazil
}

\author{
Ricardo Koroiva $^{1 * ®}$, Alessandre Pereira-Colavite ${ }^{1}{ }^{\circledR}$, Fabiane Rabelo da Costa Batista $^{2}$ \& \\ Diogo Silva Vilela ${ }^{3}$ \\ ${ }^{1}$ Universidade Federal da Paraíba, Departamento de Sistemática e Ecologia, João Pessoa, PB, Brasil. \\ ${ }^{2}$ Instituto Nacional do Semiárido, Campina Grande, PB, Brasil. \\ ${ }^{3}$ Pesquisador Autônomo, Rua Jaime Bilharinho, 575, 38065-280, Uberaba, MG, Brasil. \\ *Corresponding author: ricardo.koroiva@gmail.com
}

\begin{abstract}
KOROIVA, R., PEREIRA-COLAVITE, A., BATISTA, F.R.C., VILELA, D.S. Checklist and contribution to the knowledge of the odonatofauna of Paraíba state, Brazil. Biota Neotropica 21(3): e20211196. https://doi.org/10.1590/1676-0611-BN-2021-1196.
\end{abstract}

\begin{abstract}
We present the first listing of odonatan species (Insecta: Odonata) that occur in the state of Paraíba, Brazil. There are 49 species and 29 genera registered, making Paraíba the third in number of species among the Brazilian states of northeastern region. The families with the largest number of species were Libellulidae, with 31 species and 15 genera, followed by Coenagrionidae with 11 species and 7 genera. Interior regions of the state are undersampled, which should still lead to an underestimated number of species. In addition, we present taxonomic notes of two species collected during our expeditions: males of Progomphus dorsopallidus Byers, 1934 and females of Macrothemis griseofrons Calvert, 1909. Here, we detail important characteristics and present figures to aid their morphological identifications.

Keywords: Brazilian northeastern; List of species; Anisoptera; Zygoptera; Progomphus dorsopallidus; Macrothemis griseofrons.
\end{abstract}

\section{Checklist e contribuição para o conhecimento da odonatofauna do Estado da Paraíba, Brasil}

Resumo: Apresentamos a primeira lista de espécies de libélulas (Insecta: Odonata) que ocorrem no estado da Paraíba, Brasil. Há 49 espécies e 29 gêneros registrados, tornando a Paraíba a terceira em número de espécies entre os estados brasileiros da região Nordeste. As famílias com maior número de espécies foram Libellulidae, com 31 espécies e 15 gêneros, seguido por Coenagrionidae com 11 espécies e 7 gêneros. As regiões do interior do estado estão sub amostradas, o que deve levar a um número subestimado de espécies. Além disso, apresentamos notas taxonômicas de duas espécies coletadas durante nossas expedições: machos de Progomphus dorsopallidus Byers, 1934 e fêmeas de Macrothemis griseofrons Calvert, 1909. Aqui, detalhamos características importantes e apresentamos figuras para auxiliar em suas identificações morfológicas.

Palavras-chave: Nordeste brasileiro; Lista de espécies; Anisoptera; Zygoptera; Progomphus dorsopallidus; Macrothemis griseofrons. 


\section{Introduction}

Odonates (Insecta: Odonata) are an important group of aquatic insects participating in food chains either as an effective predator or as prey for vertebrates (May 2019). They have great appeal to the general public, being considered as "flag species", and have been used as animal models for behavior investigations and more recently as signals of environmental quality (Amorín et al. 2010, Cordoba-Aguilar 2009). In Brazil, 749 species are registered (Olaya 2019), however, with heterogeneous taxonomic knowledge in the different states.

Available mainly in the central-south region (e.g. Koroiva et al. 2017, Rodrigues et al. 2018, Vilela et al. 2020), lists of odonatan species are still scarce in the northeastern region of Brazil, despite the increase in knowledge of this region in recent years. Considering the nine Brazilian federal states in the Northeastern region, odonatological information is available for six states. The State of Alagoas has about 48 species (see Santos et al. 2020) while Ceará and Piauí have 73 and 26 species, respectively (Takiya et al. 2016). The State of Bahia has 56 species (Firme et al. 2019), however, more than three times this number has already been registered and not yet published (M. Rodrigues com. Pers.). Recently, Santos et al. (2020) released a survey of 34 species for Sergipe, while Bastos et al. (2019) identified 48 species for the State of Maranhão.

Absent from this list is the State of Paraíba. This state is located in the eastern portion of the Northeastern of Brazil, occupies $0.66 \%$ of the Brazilian territory and only the 20th position of territorial extension of Brazilian states (Mendes et al. 2012). The mosaic vegetation found in Paraíba ranges from Atlantic Forest biome along the coast to a semiarid region (Caatinga) in the interior. The first biome is considered a hotspot' region of biodiversity in the world, being the most threatened rainforest in Brazil (Rezende et al. 2018). The other biome (Caatinga), despite being considered intact for a long time, nowadays is known to have a great anthropic effect on its ecosystem mainly caused by cattle industry and bad management of water resources (Silva \& Barbosa 2017). Regarding odonates, few studies have been dedicated to increasing knowledge about its fauna in Paraíba and almost all of which are restricted to taxonomic descriptions and specific information about species of large distribution (e.g. Machado 1995, Carvalho \& Bravo 2014, Nobre 2016).

Considering this information gap, the main objective of this study was to present the diversity of odonatan species in Paraiba state through the bibliographic record and recent sampling excursions. Additionally, we provide some taxonomic notes on two poorly known species found in the Northeastern region of Brazil: Progomphus dorsopallidus Byers, 1934, a species rare in collections that we provide additions to male description and Macrothemis griseofrons Calvert, 1909, whose female description was also augmented, both collected during our expeditions.

\section{Material and Methods}

\section{Study area}

The state of Paraíba has an area of $56.467 \mathrm{~km}^{2}$ (IBGE 2019) and stands out for the predominant presence of the Caatinga Biome. The state is bordered by the states of Pernambuco, Ceará and Rio Grande do Norte (Figure 1). The relief of the state is characterized by plains, plateaus and tabular and flat depressions, with about $90 \%$ of the territory located

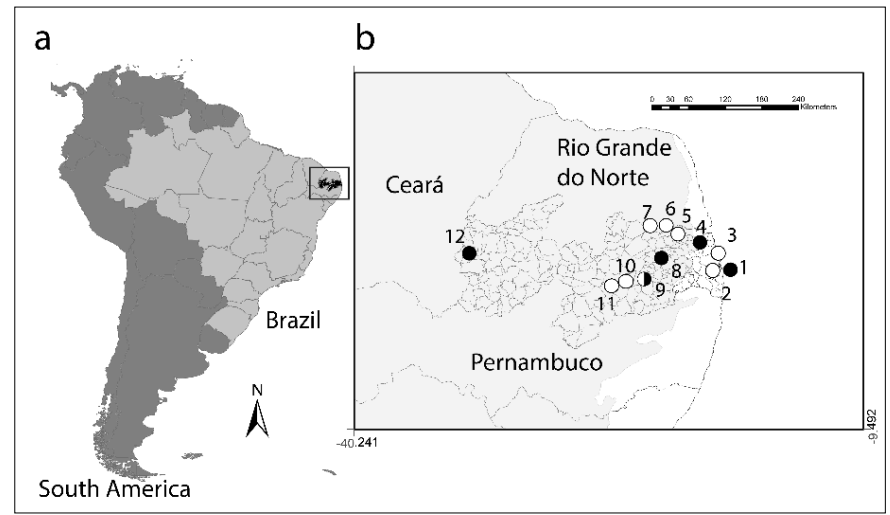

Figure 1. Sampling area. (a) Map of South America (dark grey) highlighting the geopolitical division of Brazil (grey) and Paraíba State (black); (b) Municipalities with Odonata recorded in Paraíba State highlighting Caatinga (soft grey) and Atlantic forest biomes (white). Black circle, municipalities with sampling recorded in the literature; white circle, municipalities with sampling carried out in this study; half black circle, municipality with sampling carried out by both the literature and this study. Municipalities: 1, João Pessoa; 2, Santa Rita; 3, Lucena; 4, Mamanguape; 5, Caiçara; 6, Tacima; 7, Araruna; 8, Areia; 9, Campina Grande; 10, Boa Vista; 11, Cabaçeiras; 12, Cajazeiras.

below $600 \mathrm{~m}$ in altitude (IDEME 2014). The hydrographic network consists of eleven basins, where the water system is characterized by the predominance of temporary rivers, due to long periods of drought in the interior of the state, and the presence of important perennial rivers, such as Paraíba and Piranhas rivers. In order to mitigate the effects of the dry seasons, many dams were built throughout the state (IDEME 2014). According to the Köppen climate classification, the different regions of the state can be classified as "As", "Bsh", "Aw" and "Am" types (Francisco et al. 2015). The average annual precipitation varies between $300 \mathrm{~mm}$ in the western and central region of the state to 1900 $\mathrm{mm}$ in the coastal sector and the average temperatures are above $24^{\circ}$ C (Francisco et al. 2015).

\section{Taxonomic list elaboration}

To prepare the species list, we carried out samplings and followed the methodology used by Koroiva et al. (2020a). First, we conducted samplings in eight municipalities (23 sampling sites) in Paraíba during 2020 and 2021: Araruna (-6.596052, -35.726025; -6.505297, -35.767449; -6.49901, -35.763893), Boa Vista (-7.369703, -36.308986), Cabaceiras (-7.365301, -36.243216; -7.379293, -36.300225; -7.376817, -36.309105; -7.376034, -36.322289), Caiçara (-6.611859, -35.470029), Campina Grande (-7.277802, -35.970657; -7.277554, -35.971868; -7.274477, -35.964059; -7.269109, -35.974413; -7.275961, -35.966894; $-7.275912,-35.965903 ;-7.277288,-35.972267)$, Lucena (-6.894775, $-34.874688 ;-6.896821,-34.878103 ;-6.897269,-34.881032)$, Santa Rita (-7.151667, -34.961308; -7.000965, -34.98836) and Tacima $(-6.590482,-35.46025 ;-6.48637,-35.643069)$ (Figure 1). Odonata sampling, euthanasia, and transport was authorized by the Brazilian Biodiversity Information and Authorization System (SISBIO), Chico Mendes Institute for Biodiversity Conservation (ICMBio), Ministry of Environment (MMA) (SISBIO authorization number 74324-2). The field samplings followed the methodology presented in Vilela et al. (2020). We also obtained information from the Entomological Collection of the Department of Systematics and Ecology of the Federal University of Paraíba (DSEC), where all the specimens sampled in this project were also deposited. 
Additional data were collected in 12 publications (Bastos et al. 2019, Belle 1983, Costa et al. 2002, 2006, Machado 1995, 2010, Nobre 2016, Pinto \& Carvalho 2012, Pinto 2013, Lacerda \& Machado 2019, St. Quentin 1973, Takiya et al. 2016), published between 1973 and 2019, and on the website "Catalogo Taxonômico da fauna do Brasil" (http:// fauna.jbrj.gov.br; "Taxonomic Catalog of Fauna of Brazil" in English; Pinto 2021). Additionally, we present the municipality where the specimens were sampled in Paraíba state, when the data was available (Figure 1). In cases where there is no previous record of the species from Paraíba state by other document, these must be considered new records. For the systematic classification, we follow Paulson \& Schorr (2020) and Lorenzo-Carballa et al. (2021).

\section{Taxonomic notes}

Specimens of $P$. dorsopallidus and $M$. griseofrons were collected during an expedition to the Pai Mateus farm (also known as Tapera farm), Cabaceiras (site 11), Paraíba state, Brazil (Figure 1), between June and July 2020. This farm is located in the permanent preservation area of Cariri - Lajedo do Pai Mateus (Silva et al. 2017) and has a farm hotel and two important natural tourist attractions, "Lajedo do Pai Mateus" and "Lajedo Manoel de Souza".

Specimens were scanned with an Epson V600 Perfection at colored 1200 dpi with $200 \%$ magnification. Illustrations were made using trace paper and scanned with Epson V600 Perfection at black and white 1200 dpi with $100 \%$ magnification. Morphological terminology for $P$. dorsopallidus follows Belle $(1973,1994)$, for $M$. griseofrons we follow Garrison et al. (2006), and Costa (1991) except for wing venation. We follow Riek \& Kukalová-Peck (1984) for wing venation characters. All measurements are in millimeters (mm). Photos of Progomphus dorsopallidus Holotype kindly sent by Dr. Erika Tucker from the Insect Collection Manager from the University of Michigan, MI, USA.

Abbreviations: AL, abdomen length (including cercus); Ax, antenodal crossveins; Ce, cercus; Ep; epiproct; FW, fore wing; HW, hind wing; Pa, paraproct; Pt: costal edge of FW pterostigma; Px, postnodal crossveins; S1-10, abdominal segments; TL, total length (including cercus).

\section{Results}

\section{Species list}

The total number of Odonata species registered in Paraíba is 49 (Table 1). We sampled 410 specimens from 36 species and 22 genera. Some species registered in this study are presented in Figures 2 and 3 . The total number of genera registered for the state is 29 , distributed in six families: Libellulidae is the family with the largest number of records, with 15 genera and 31 species, followed by Coenagrionidae with 7 genera and 11 species, Gomphidae with 4 genera and 4 species. Calopterigydae, Heteragrionidae and Lestidae presented one genus and one species.

\section{Taxonomic notes}

Additions to the original male description of Progomphus dorsopallidus Byers, 1934

(Figures 4-7)

Material examined. 1§, Brazil, Paraíba State, Cabaceiras, Fazenda do Lajedo do Pai Mateus (-7.3760, -36.3222), 437m, 25.vii.2020, R. Koroiva \& V.G.N. Gomes-Koroiva leg.
Head. Mouthparts light brown, bearing dark setae; eyes dark brown (blue-grey when alive); antenna dark brown, dorsal portion of scape grey, remainder dark brown; postclypeus, antefrons, postfrons light brown; vertex dark brown; postocellar ridge dark brown, with a deep concavity at its middle; occiput dark green at its middle, black margins with a fringe of pale setae; posterior area of head pale colored laterally, darkening toward the middle.

Thorax. Anterior lobe of prothorax dark brown, with pale spots on each side; medial lobe dark brown; posterior lobe rounded, mostly pale, darkening toward the base. Pterothorax mostly pale green/brown colored with darker marks as follows: mesepisternum pale green with two thin stripes parallel to middorsal carina, slightly surpassing its anterior $1 / 2$, a thick antehumeral stripe covering most of its lower $1 / 2$, connected with a smaller stripe that surpasses the suture to mesepimeron; mesepimeron brown, with a small stripe covering its upper $1 / 2$; metepisternum brown, with a thick stripe covering most of its middle portion; metepimeron brown, with a thin stripe covering its upper $1 / 2$.

Wings. Hyaline, with a light brown tinge, venation brown; pterostigma light brown with dark contours on all four wings, occupying $5.5-6$ cells on left wings and 5 cells on right wings. Fore wings (FW) with 4 paranal cells, area posterior to $\mathrm{CuA}$ one cell wide for first 2 cells, then increasing to 2 cells for a distance of 2 cells, then decreasing to 1 cell; antenodal crossveins on FW 14/14, on HW 9/9, first and fifth thickened in all wings; postnodal crossveins on FW 7/7, on $\mathrm{HW} 8 / 8$; basal subcostal crossvein present in all wings; triangles 3-celled and subtriangles 2-celled in all wings.

Abdomen. S1-2 mostly dark brown, S1 lacking a midventral tubercle, becoming paler below; auricles dark brown externally, pale green internally, bearing minute denticles on posterior margin; S3-7 with a dark brown ring at $1 / 2$, overall coloration light brown in the anterior 3/5, remainder dark brown (broken between S6-7); S8 mostly dark brown, becoming brown below; 99 dorsally dark brown, brown laterally becoming black toward venter, with a black spot on each medio-anterior side; S10 mostly brown, with a black anterodorsal stripe. Posterior hamuli stocky, with a thick well-developed hook bearing 5 small basoventral tubercles in a straight row, overall coloration mostly brown with basal paler areas, apex of hook black.

Anal appendages. Cercus with a pronounced basal externo-lateral dilatation, bearing a tooth with acute apex, obliquely oriented; inferior carina of cercus curved, with a row of several minute blunt denticles. Epiproct forcipate, supero-external tooth with blunt and rounded apex; tip of epiproct not bifid, with 3 (left) and 4 (right) blunt rounded teeth.

Measurements. TL 41.5; AL 29.6; FW 22.2; HW 21.1; Pt 2.9.

Remarks. P. dorsopallidus (Figure 4) fits best in the guyanensis Group, proposed by Belle (1990), by having cerci with a sharply pointed basal externo-lateral dilatation (Figure 5), and can be separated from its congeners by the following character combination: in lateral view, cercus (Figure 5) with a pronounced basal externo-lateral dilatation bearing several minute blunt denticles (shared with $P$. mexicanus, and P. amarillus), not so pronounced in the other species; supero-external tooth of epiproct forceps with blunt and rounded apex, bearing 3 or 4 blunt rounded teeth (Figure 6), and a stocky hamule with a thick developed hook. The epiproct structure of $P$. dorsopallidus (Figure 7) resembles those of $P$. mexicanus, and they can be separated mainly by their size (reaching $1 / 2$ of cerci in $P$. mexicanus, $3 / 4$ of cerci in $P$. dorsopallidus), tip of supero-external tooth is acute in P. mexicanus, 
Koroiva, R. et al.

Table 1. Odonata species recorded for Paraiba State, Brazil. The term "Not informed" was used for records without information about municipality.

Scientific name
ANISOPTERA
Libellulidae
Anatya guttata (Erichson in Schomburgk, 1848)
Brachymesia furcata (Hagen, 1861)
Brachymesia herbida (Gundlach, 1889)
Diastatops obscura Fabricius, 1775
Eryhtrodiplax umbrata (Linnaeus, 1758)
Erythemis carmelita Williamson, 1923
Erythemis credula (Hagen, 1861)
Erythemis haematogastra Burmeister, 1839
Erythemis mithroides (Brauer, 1900)
Erythemis peruviana (Rambur, 1842)

Erythemis plebeja (Burmeister, 1839)

Erythemis vesiculosa (Fabricius, 1775)

Erythrodiplax avittata Borror, 1942

Erythrodiplax basalis (Kirby, 1897)

Erythrodiplax fusca (Rambur, 1842)

Erythrodiplax leticia Machado 1996

Erythrodiplax media Borror, 1942

Macrothemis griseofrons Calvert, 1909

Miathyria marcella (Selys in Sagra,1857)

Micrathyria catenata Calvert, 1909

Micrathyria hesperis Ris, 1911

Micrathyria ocellata Martin, 1897

Oligoclada aff. borrori Santos, 1945

Orthemis aequilibris Calvert, 1909

Orthemis discolor (Burmeister, 1839)

Pantala flavescens (Fabricius, 1798)

Perithemis tenera (Say, 1840)

Tramea cophysa Hagen, 1867

Tramea darwini Kirby 1889

Uracis imbuta (Burmeister, 1839)

Zenithoptera lanei Santos, 1941

Gomphidae

Phyllocycla brasilia Belle, 1975

Phyllogomphoides annectens (Selys, 1869)

Progomphus dorsopallidus Byers, 1934

Zonophora calippus Selys, 1869

\section{ZYGOPTERA}

Calopterygidae

Hetaerina $\mathrm{sp}$

Coenagrionidae

Acanthagrion gracile (Rambur, 1842)

Argia aff. reclusa Selys, 1864

Enallagma novaehispaniae (Calvert,1907)

Municipality

References

Santa Rita

Boa Vista, Cabaceiras, Campina Grande Lucena

Santa Rita

Campina Grande

Tacima

Campina Grande

João Pessoa

João Pessoa

Cabaceiras, João Pessoa

Araruna, Areia, Tacima, João Pessoa

Campina Grande, João Pessoa

Araruna, Cabaceiras, Campina

Grande, Santa Rita, Tacima

Areia

Cabaceiras

Araruna, Campina Grande, Cajazeiras, Santa Rita

Santa Rita

Boa Vista, Cabaceiras, Campina

Grande

Areia, Cabaceiras, Caiçara, Campina

Grande, Lucena, Tacima

Not informed

Cabaceiras, Caiçara, Campina Grande

Araruna, Cabaceiras, Campina Grande, Lucena

Lucena

Araruna, Lucena

Campina Grande, Tacima

Araruna, Cabaceiras, Campina Grande

Araruna, Boa Vista, Cabaceiras,

Caiçara, Campina Grande, Tacima

Boa Vista, Cabaceiras, Tacima

Campina Grande

Santa Rita

Not informed

Areia

João Pessoa

Cabaceiras

João Pessoa

Santa Rita

Areia, Araruna, Santa Rita

Santa Rita

Areia, Araruna, Santa Rita
This study

This study

This study

Bastos et al. 2019; This study

This study

This study

This study

Bastos et al. 2019; Pinto 2013

Pinto 2013

Pinto 2013; This study

Carvalho \& Bravo 2014; Pinto 2013;

This study

Pinto 2013; This study

This study

Carvalho \& Bravo 2014

This study

Machado 1995; Nobre 2016; This study

This study

This study

Carvalho \& Bravo 2014; This study

Costa et al. 2002

This study

This study

This study

This study

This study

This study

Costa et al. 2006, This study

This study

This study

This study

Pinto 2021

Carvalho \& Bravo 2014

St Quentin 1973

This study

Belle 1983

This study

Carvalho \& Bravo 2014; This study

This study

Carvalho \& Bravo 2014; This study 
Continuation...

Ischnura capreolus (Hagen, 1861)

Ischnura fluviatilis Selys, 1876

Phoenicagrion flammeum (Selys 1876)

Telebasis corallina (Selys, 1876)

Telebasis filiola (Perty, 1834)

Mecistogaster kesselringi Soldati \&

Machado, 2019

Mecistogaster mielkei Soldati \& Machado, 2019

Mecistogaster nordestina Soldati \& Machado, 2019

\section{Heteragrionidae}

Heteragrion sp.

Lestidae

Lestes forficula Rambur, 1842
Areia, Araruna, Cabaceiras, Caiçara,

Lucena, Santa Rita, Tacima

Areia, Cabaceiras, Campina Grande, Lucena

Areia

Campina Grande, João Pessoa

Areia, Araruna, Cabaceiras, Caiçara, Campina Grande, João Pessoa

João Pessoa, Mamanguape

João Pessoa

João Pessoa

João Pessoa

Areia, Campina Grande, Tacima
Carvalho \& Bravo 2014; Pinto 2021; Takyia et al. 2016; DSEC; This study

Carvalho \& Bravo 2014; This study

Machado 2010

Pinto 2021; Pinto \& Carvalho 2012; This study

Carvalho \& Bravo 2014; Pinto 2021, Pinto \& Carvalho 2012; This study

Lacerda \& Machado 2019

Lacerda \& Machado 2019

Lacerda \& Machado 2019, DSEC

DSEC Carvalho \& Bravo 2014; This study

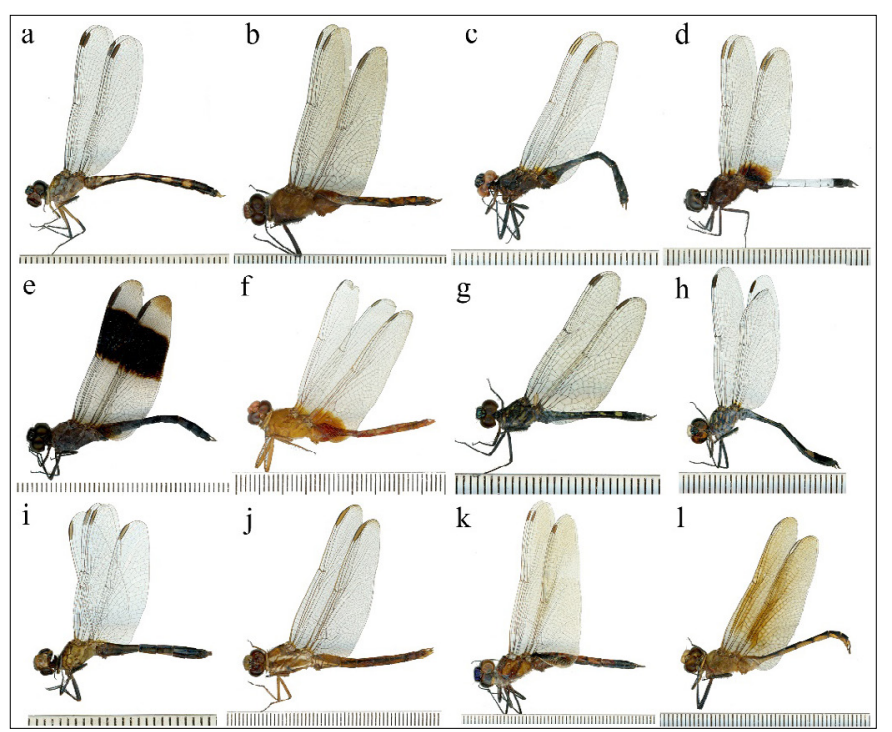

Figure 2. Examples of dragonflies (Odonata:Anisoptera) collected in Paraiba State, Brazil. (a) Anatya guttata; (b) Brachymesia furcata; (c) Erythemis credula; (d) Erythrodiplax media; (e) Erythrodiplax umbrata; (f) Erythemis carmelita; (g) Micrathyria hesperis; (h) Micrathyria ocellata; (i) Oligoclada cf. borrori;

(j) Orthemis aequilibris; (k) Tramea cophysa; (1) Brachymesia herbida.

blunt in P. dorsopallidus, and the tip of epiproct ends in 3 or 4 blunt rounded teeth in $P$. dorsopallidus, whereas in $P$. mexicanus it ends in two teeth. It should be added that the two species (P. dorsopallidus and P. mexicanus) are far separated in distribution.

Habitats, biology and conservation. $P$. dorsopallidus has a wide distribution range in south America, mainly concentrated in coastal regions, where it occurs, for instance, in the states of Ceará and Espírito Santo (Montes-Fontalvo et al. 2021). Due to its large distribution and its occurrence in protected areas, it has been assessed as LC (least concern)

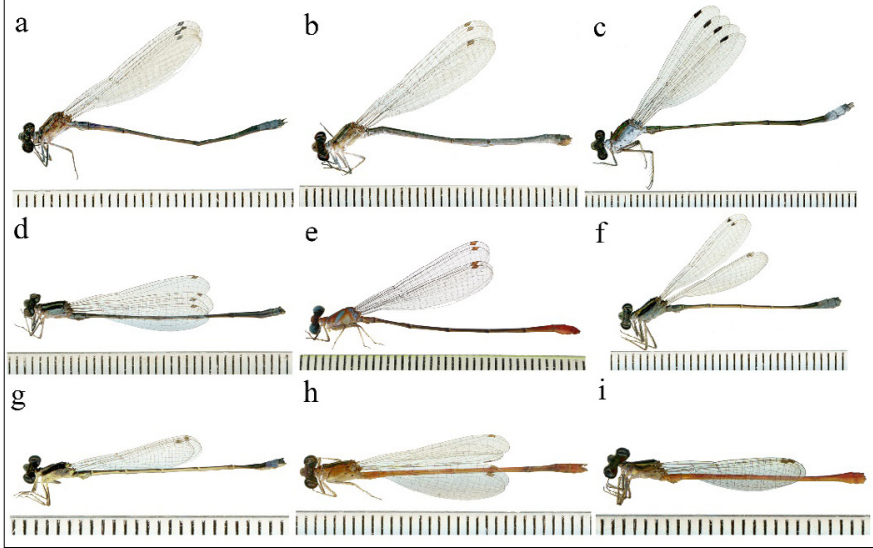

Figure 3. Examples of damselflies (Odonata:Zygoptera) collected in Paraiba State, Brazil. (a) Enallagma novaehispaniae - male; (b) Enallagma novaehispaniae - female; (c) Lestes forficula; (d) Acanthagrion gracile; (e) Phoenicagrion flammeum; (f) Ischnura fluviatilis; (g) Ischnura capreolus; (h) Telebasis corallina; (i) Telebasis filiola.

by IUCN, which means that the species is not under threat of extinction (Montes-Fontalvo et al. 2021). This species inhabits streams in semi- or open areas and is not found inside forested areas (De Marmels 2005). In Paraíba state, we also found this species in a stream located in an open area, thus corroborating the literature record.

Additions to the female description of Macrothemis griseofrons Calvert, 1909

(Figures 8-10)

Material examined. 4우, Brazil, Paraíba State, Cabaceiras, Lagoas PB-160 Road (-7.3653, -36.2432), 25-27.vi.2020, R. Koroiva \& V.G.N. Gomes-Koroiva leg.; 2 , Brazil, Paraíba State, Cabaceiras, Estacionamento Saca-de-lã (-7.3760, -36.3222), 27.vi.2020, R. Koroiva 


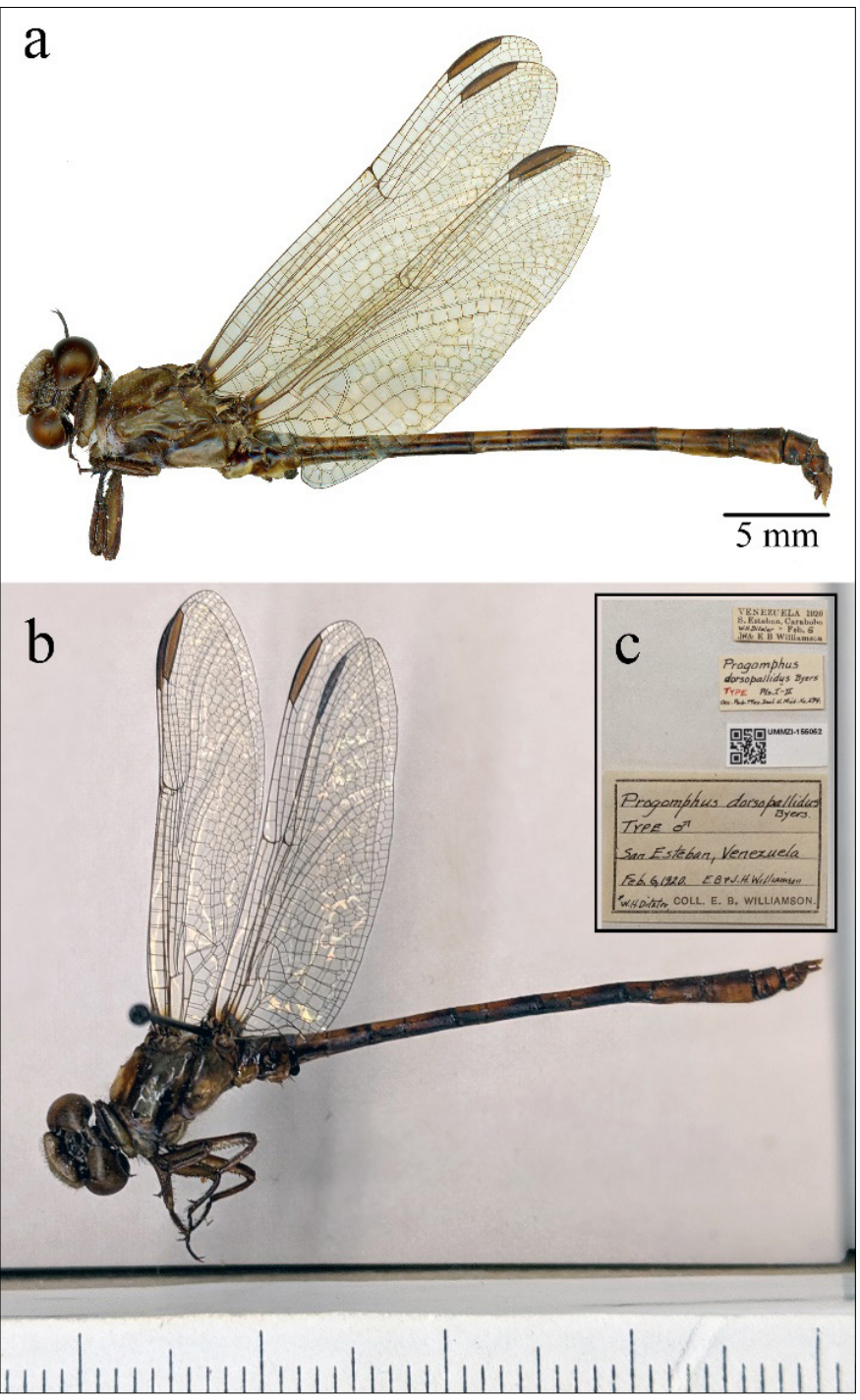

Figure 4. Progomphus dorsopallidus: lateral view of habitus; (a) male from Cabaceiras, Paraíba State; (b) Holotype from San Esteban, Venezuela.

\& V.G.N. Gomes-Koroiva leg.; 1 9 , Brazil, Paraíba State, Cabaceiras, Represa Casa do Pai Mateus (-7.3792, -36.3002), 25-27.vi.2020, R. Koroiva \& V.G.N. Gomes-Koroiva leg.; 1 q , Brazil, Paraíba State, Boa Vista, Lagoa entre Lajedos (-7.3697, -36.3089), 27.vi.2020, R. Koroiva \& V.G.N. Gomes-Koroiva leg.

Head. Mouthparts pale colored; eyes dark; antenna dark brown, dorsal portion of scape brown, remainder black (Figure 8); postclypeus, antefrons, postfrons brown/dark grey; vertex dark brown; occiput dark brown; posterior area of head with a diffuse brown/pale coloration as in Figure 9.

Thorax. Overall coloration brown (varying as in Figure 10), with a pale oblique lateral stripe (roughly similar to the male) and with two thin stripes parallel to middorsal carina; darker brown stripes on the following areas: a thick humeral stripe, covering most of the mesepisternum; a thick stripe covering the lower portion of mesepisternum, surpassing the suture and covering the upper half of mesepimeron; a stripe covering the lower half of metepisternum; legs light brown, with $6+1$ spines on metafemur.

Wings. Hyaline with a circular infumated spot on each FW reaching from postnodal $1 / 4$ until the tip of the wings, and a small brown spot on the HW base, not reaching Ax 1 level; Mspl in FW distinct; FW triangle crossed, subtriangle with 3 cells; arculus proximal to Ax 2 in FW and $\mathrm{HW}$; $13 \mathrm{Ax}$ in FW, 10 in HW; 8 Px in FW, 8 in HW.

Abdomen. Overall coloration of S1-7 brown, with lateral darker coloration; S8-10 dark brown, dorsally black; cerci dark brown, as long as $1.5 \mathrm{x}$ the $\mathrm{S} 10$ length; vulvar lamina ' $\mathrm{U}$ ' shaped, with blunt edges.

Measurements. TL 39.2; AL 27.8; FW 33.1; HW 31.8; Pt 2.6.

Remarks. The female of $M$. griseofrons can be distinguished by other female congeners by the following character combination: a circular infumated spot on each FW tip (basal spot in M. absimile, hyaline in $M$. calliste), a pale oblique lateral thoracic stripe (absent in M. absimile and $M$. calliste), vulvar lamina 'U' shaped, with blunt edges (with a small median excision in M. absimile, and a larger median excision in M. calliste).

Habitats, biology and conservation. M. griseofrons occurs in the states of Bahia, Ceará and Pernambuco (Santos 1946, Nobre and Carvalho 2014). However, there are only four known records to this species so far, being three of these very old, dating before 1945. Current distribution of this species is currently unknown and it was assessed as DD (data deficient) by IUCN (Vilela \& Guillermo-Ferreira 2021), which means that the amount of recent records are insufficient to perform a proper assessment, pending on new literature records such as the one we present here. M. griseofrons was collected in lentic habitats, where it was found perching on the riparian vegetation.

\section{Discussion}

\section{Species list}

The 49 species listed in the state of Paraíba represent about $6.54 \%$ of the known species in Brazil (749 species). With the results presented in this study, the state of Paraíba is the third in number of species in the northeast region of Brazil, behind Ceará (73 species; Takiya et al. 2016) and Bahia (54 species; Firme et al. 2019). In relation to other states of Brazil, the number is still far from the number registered to Amazonas (335 species; Koroiva et al. 2020b) and Minas Gerais (308 species; Vilela 2021). Overall, $40(82 \%)$ of the species recorded to Paraíba state fall under the LC category of conservation by IUCN, meaning widespread species with several literature records and that occurs in protected areas. Two species (M. griseofrons and P. brasilia, 4\%) were assessed as DD, with insufficient assessment data, and five species (M. kesselringi, $M$. mielkei, M. nordestina, O. borrori, and Telebasis filiola, 10\%) were never assessed for its conservation status. None of the species recorded so far to Paraíba state are endemic. The samples in the state are mainly concentrated close to municipalities with the presence of important universities and research institutes such as João Pessoa, Campina Grande and Areia. Similar as evidenced by Koroiva et al. (2020a) for the State of Amazonas, it is necessary to carry out more field samples for the interior of Paraíba, which should provide new records to this list.

\section{Taxonomic notes}

About $P$. dorsopallidus, the most interesting feature about the epiproct structures observed here is the variation of the blunt rounded teeth on the right and left forceps. On the holotype, the left and right forceps has two blunt teeth (Figure 6). On the examined male, there is one variation: left forceps with three blunt teeth (Figure 6) and the right with two, as in the holotype. The same occurred with two additional 


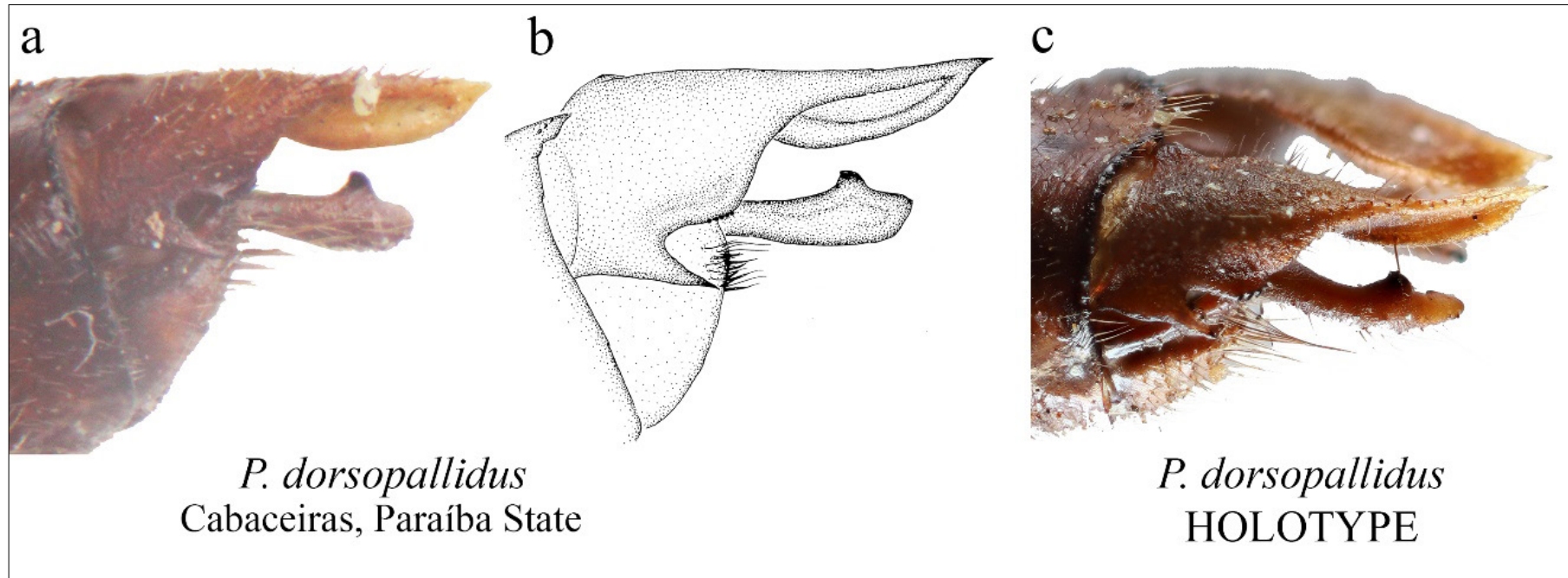

Figure 5. Progomphus dorsopallidus: lateral view of anal appendages; (a-b) male from Cabaceiras, Paraíba State; (c) Holotype from San Esteban, Venezuela.

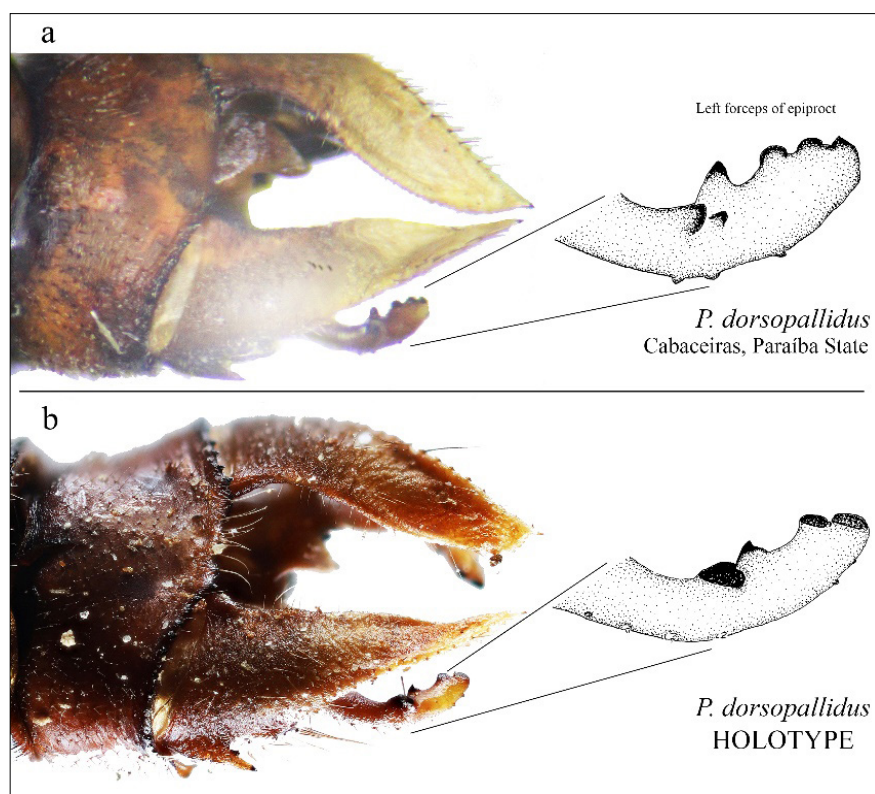

Figure 6. Progomphus dorsopallidus: dorsolateral view of anal appendages, showing the left epiproct forceps in detail; (a) male from Cabaceiras, Paraíba State; (b) Holotype from San Esteban, Venezuela.

males that we examined but were not available to include in this study, and one additional male photographed by Dr. Jurg DeMarmels (pers. comm.). At first, we thought our male to be a new species, because cerci and epiproct structures differed greatly from the other species of Progomphus, drawn by Belle $(1973,1994)$ and other authors. Comparing our specimen with the original description by Byers (1934), thoracic coloration patterns and hamuli are very similar to our specimen; however the drawings of the appendages drove our attention away, because they are very different from the actual structure. Anyway, we asked for photographs of the holotype, which were kindly provided by Dr. Erika Tucker, the Insect Collection Manager from the University of Michigan. Comparing our specimen with the holotype, we had no doubt that our specimen represents $P$. dorsopallidus due to cerci and epiproct morphology, in addition to the coloration patterns.

On the account of $M$. griseofrons, after Calvert's description of the species in 1909, Navás (1916) described Cendra cearana, which later

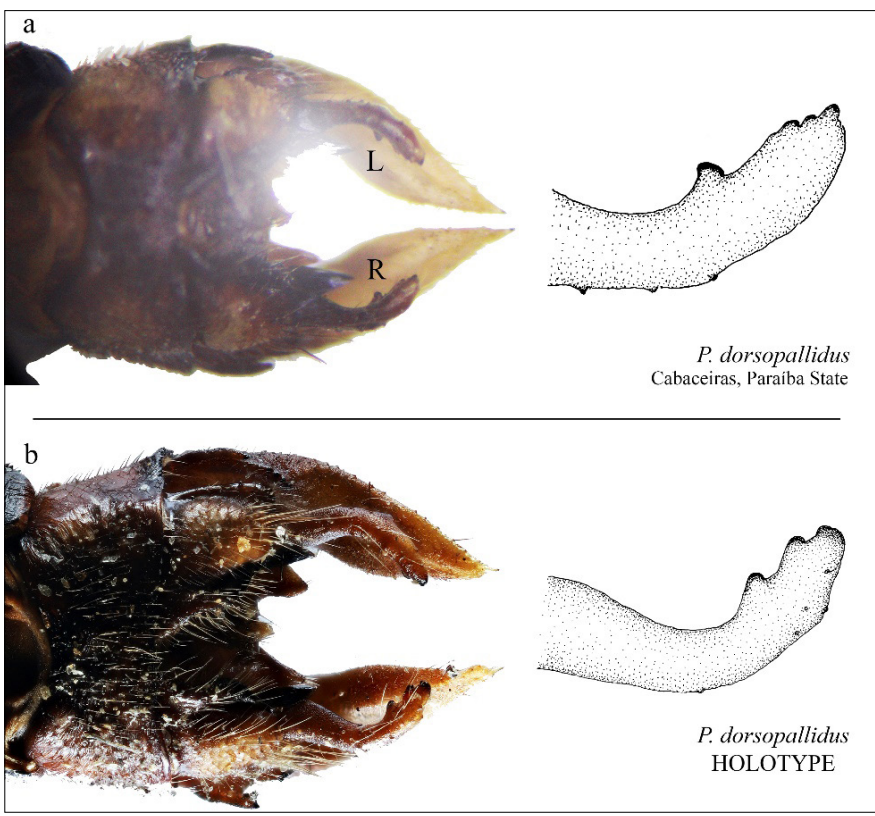

Figure 7. Progomphus dorsopallidus: ventral view of anal appendages, showing both epiproct forceps's in detail; (a) male from Cabaceiras, Paraíba State; (b) Holotype from San Esteban, Venezuela.

was synonymized with $M$. griseofrons by Santos (1946). The female was never treated by Calvert and Santos, but was treated by Navás's study in Latin. He never figured the female structures and our study brings additional information on Macrothemis females, which are often difficult to identify in the absence of males (Garrison et al. 2006). Also, by adding a new record to the literature (which includes a record within a protected area), we may help future assessments by IUCN to determine the current conservation status of this species.

\section{Final Considerations}

The knowledge about the Odonata order has had a unique improvement in the last 10 years in Northeastern Brazil. The presence of specialists and new expeditions demonstrate the importance of participation and exchange between researchers for the taxonomic improvement on insects. Despite 


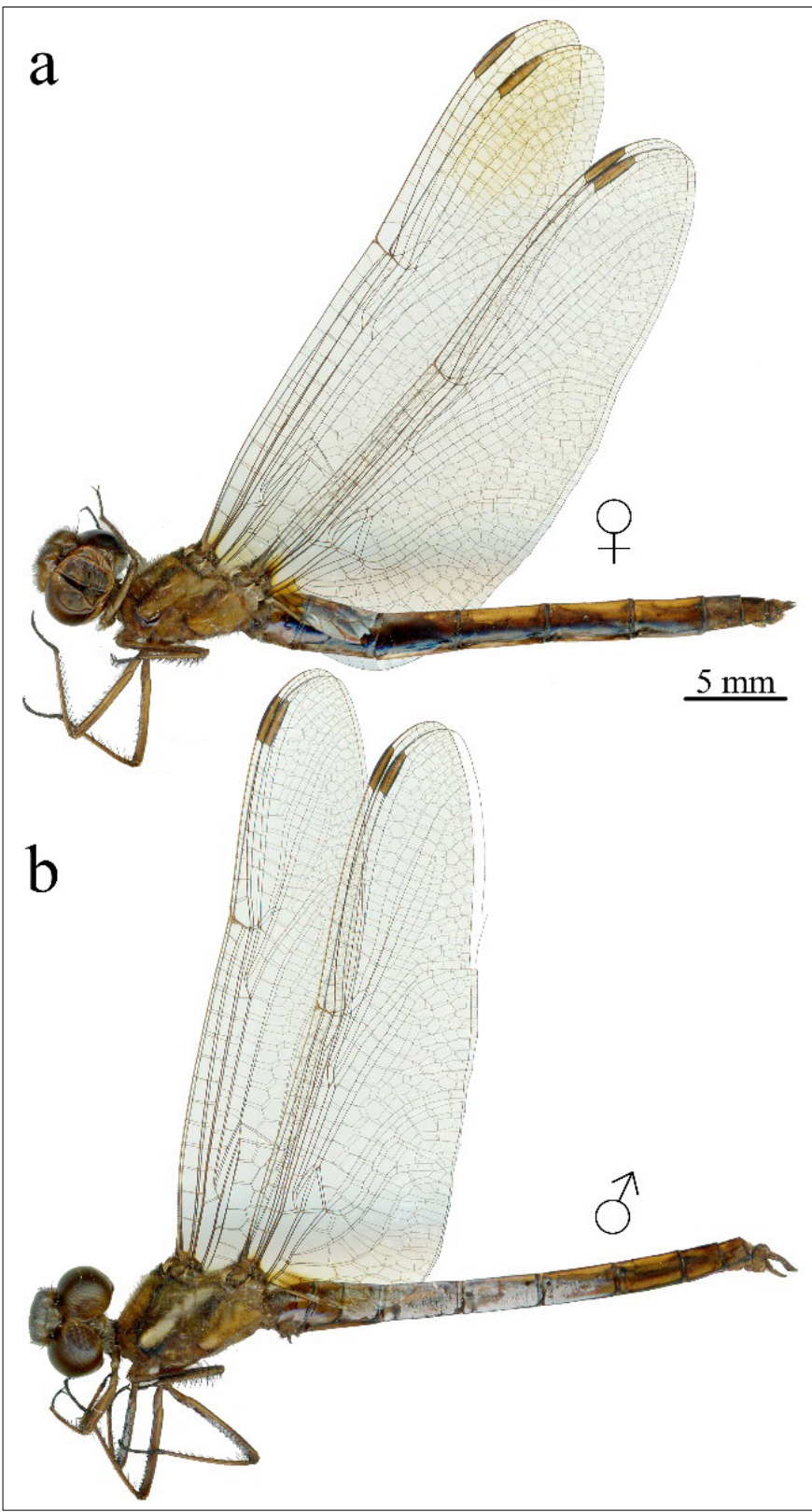

Figure 8. Macrothemis griseofrons: lateral view of habitus; (a) female and (b) male from Cabaceiras, Paraíba State.

these advances, until now, this and other studies published have not carried out a wide sampling in these states, which indicates that these numbers are still quite underestimated. Keeping in mind the importance of the correct species identification, the taxonomic notes presented for Progomphus dorsopallidus Byers, 1934 and Macrothemis griseofrons Calvert, 1909 highlight the need for improvements of descriptions and revisions even for species with wide distribution. In this sense, the increase in taxonomic research and samplings in northeastern Brazil plays a key role in improve knowledge about the diversity of odonatan species, not exclusively for this region, but for the entire Neotropical area.

\section{Acknowledgements}

We are thankful to Vanessa Gabrielle Nobrega Gomes-Koroiva and Gerson Lima for the assistance of sampling. We are grateful to

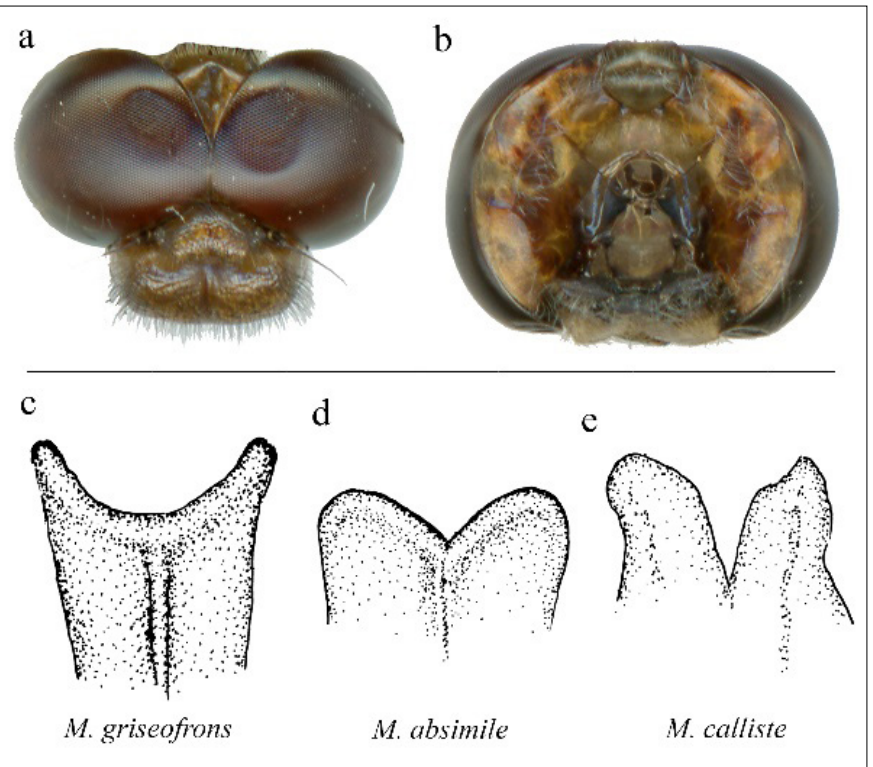

Figure 9. Macrothemis griseofrons: dorsal (a) and posterior (b) views of female head. Ventral view of vulvar lamina of M. griseofrons (c), M. absimile (d) and M. calliste (e).

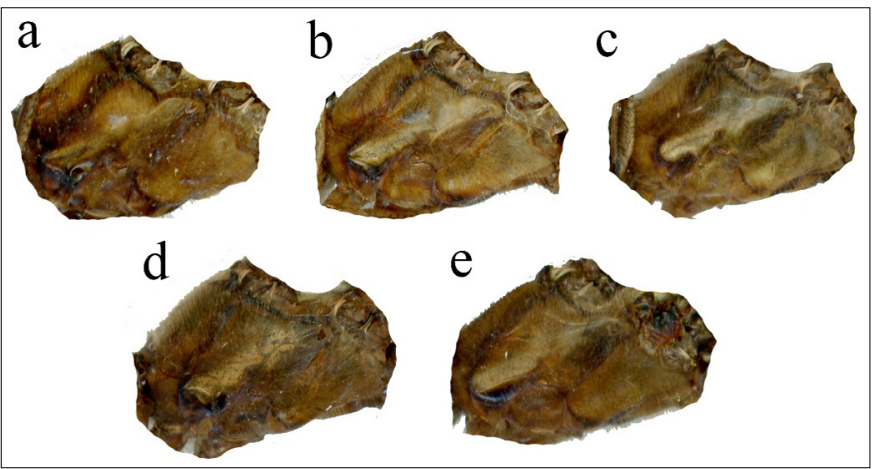

Figure 10. Macrothemis griseofrons: color variation on female thoracic pattern.

Eduardo Lucena for the cooperation that allowed us access to the Pai Mateus farm. We are also grateful to Jurg De Marmels and Erika Tucker for technical support. This work was funded by the Public Call n. 03 Produtividade em Pesquisa PROPESQ/PRPG/UFPB proposal code PVA13280-2020. This study was financed in part by the Coordenação de Aperfeiçoamento de Pessoal de Nível Superior - Brasil (CAPES) - Finance Code 001.

\section{Author Contributions}

Ricardo Koroiva: Contribution to data collection and manuscript preparation. Substantial contribution in the concept and design of the study. Contribution to critical revision, adding intellectual content.

Alessandre Pereira-Colavite: Contribution to data collection. Contribution to critical revision, adding intellectual content.

Fabiane Rabelo da Costa Batista: Contribution to manuscript preparation. Contribution to critical revision, adding intellectual content.

Diogo Silva Vilela: Contribution to data collection and manuscript preparation. Substantial contribution in the concept and design of the study. Contribution to critical revision, adding intellectual content. 


\section{Conflicts of Interest}

The authors declare that they have no conflict of interest related to the publication of this manuscript.

\section{References}

AMORÍN, MA., VILA, M. \& RIVERA, AC. 2010. Population Genetic Structure of Two Threatened Dragonfly Species (Odonata: Anisoptera) as Revealed by RAPD Analysis. In Habel J.C., Assmann T. (Eds.) Relict Species: Phylogeography and Conservation Biology. Springer, Berlin, p. 295-308.

BASTOS, R.C., BRASIL, L.S., CARVALHO, F.G., CALVÃO, L.B., SILVA, J.O. de A. \& JUEN, L. 2019. Odonata of the state of Maranhão, Brazil: Wallacean shortfall and priority areas for faunistic inventories. Biota Neotrop. 19(4):e20190734. https://doi.org/10.1590/1676-0611-bn-2019-0734 (last access on 20/04/2021).

BELLE, J. 1973. A revision of the New World genus Progomphus Selys, 1854 (Anisoptera: Gomphidae). Odonatologica 2(4):191-308.

BELLE, J. 1983. A review of the genus Zonophora Selys (Odonata, Gomphidae). Tijdschr. voor Entomol. 126:145-173.

BELLE, J. 1990. Progomphus nigellus and Phyllocycla hamata, two new dragonflies from Brazil (Odonata: Gomphidae). Tijdschr. Entomol. 133(1):27-30.

BELLE, J. 1994. On five species of Progomphus Selys from Brazil with the descriptions of four new taxa (Odonata: Gomphidae). Zool. Meded. 68:203-214.

BYERS, C.F. 1934. Progomphus dorsopallidus, a new species from Venezuela (Odonata-Gomphinae). Occas. Pap. Museum Zool. - Univ. Michigan 294:1-12.

CARVALHO, J. de \& BRAVO, F. 2014. Odonata do semiárido. In Bravo F., Calor A. (Eds.) Artrópodes do Semiárido: biodiversidade e conservação. Printmidia, Feira de Santana, p.83-90.

CORDOBA-AGUILAR, A. 2009. Dragonflies and Damselflies: Model Organisms for Ecological and Evolutionary Research. 1 ed. Oxford University Press, New York, USA.

COSTA, J.M. 1991. Macrothemis absimile spec. nov., a remarkable new species of Libellulidae from Brazil (Anisoptera). Odonatologica 20:233-237.

COSTA, J.M., LOURENÇO, A.N. \& VIEIRA, L.P. 2002. Micrathyria pseudhypodidyma sp. n. (Odonata: Libellulidae), com Chave das Espécies do Gênero que Ocorrem no Estado do Rio de Janeiro. Neotrop. Entomol. 31(3):377-389.

COSTA, J.M., DE SOUZA, L.O.I. \& MUZÓN, J. 2006. Descriptions of three new species of Odonata from Brazil. Zootaxa 1314(1):53-68.

DE MARMELS, J. C. 2005. La larva de Progomphus dorsopallidus Byers, 1934,(Odonata: Gomphidae), con una clave para identificar larvas de otras especies del género halladas al norte del Río Orinoco, Venezuela. Entomotrópica 20(3): 235-238.

FIRME, B.C., SANTOS, C.R., SANTOS, L.R. \& RODRIGUES, M.E. 2019 Checklist de Odonata na RPPN Veracel e áreas ao entorno, com novos registros para o Estado da Bahia. In Pinto A.P., Salles F.F., Dumas L.L., Passos M.I.S. (Eds.) Livro de resumos do V Simpósio de Insetos Aquáticos Neotropicais. SBZ, Curitiba, p.53.

FRANCISCO, P.R.M., MEDEIROS, R.M. de, SANTOS, D. \& MATOS, R.M. de. 2015. Köppen's and Thornthwaite Climate Classification for Paraíba State. Rev. Bras. Geogr. Física 8(4):1006-1016.

GARRISON, R.W., ELLENRIEDER, N. von \& LOUTON, J.A. 2006. Dragonfly Genera of the New World: An Illustrated and Annotated Key to the Anisoptera. Johns Hopkins University Press, Baltimore, USA.

IBGE. 2019. Cidades e estados. https://www.ibge.gov.br/cidades-e-estados.html (last access on 15/01/2021).

IDEME. 2014. Anuário estatístico da Paraíba. http://ideme.pb.gov.br/servicos/ anuarios-online/anuario-2014.pdf/view (last access on 15/01/2021).

KOROIVA, R., BRASIL, P.G., NEISS, U.G., VILELA, D.S. \& HAMADA, N. 2020a. Dragonflies and Damselflies (Insecta: Odonata) housed in the Invertebrate Collection of the Instituto Nacional de Pesquisas da Amazônia, Manaus, Amazonas, Brazil. Hetaerina 2(2):14-23.
KOROIVA, R., NEISS, U.G., FLECK, G. \& HAMADA, N. 2020b. Checklist of dragonflies and damselflies (Insecta: Odonata) of the Amazonas state, Brazil. Biota Neotrop. 20(1):e20190877. https://doi.org/10.1590/1676-0611bn-2019-0877 (last access on 20/04/2021)

KOROIVA, R., RODRIGUES, M.E., VALENTE-NETO, F. \& ROQUE, F.O. 2017. Odonates from Bodoquena Plateau: checklist and information about endangered species. Biota Neotrop. 16(3):e20160310. https://doi. org/10.1590/1676-0611-bn-2016-0310 (last access on 20/04/2021)

LACERDA, D.S.S. \& MACHADO, A.B.M. 2019. The damselfly genus Mecistogaster (Odonata: Pseudostigmatidae) from the Brazilian Atlantic Forest with a description of three new species and a neotype designation for M. amalia (Burmeister, 1839). Zootaxa 4668(2):207-228.

LORENZO-CARBALLA, M.O., GARRISON, R.W., ENCALADA, A.C. \& CORDERO-RIVERA, A. 2021. Darwin Returns to the Galapagos: Genetic and Morphological Analyses Confirm the Presence of Tramea darwini at the Archipelago (Odonata, Libellulidae). Insects 12(1):21.

MACHADO, A.B. 1995. Erythrodiplax leticia, sp.n. de libélula do nordeste brasileiro (Odonata, Libellulidae). Rev. Bras. Zool. 12(4):977-982.

MACHADO, A.B.M. 2010. Four new species of Phoenicagrion von Ellenrieder, 2008 from Brazil (Odonata, Coenagrionidae). Zootaxa 2517(1):44-52.

MAY, M. 2019. Odonata: Who They Are and What They Have Done for Us Lately: Classification and Ecosystem Services of Dragonflies. Insects 10(3):62.

MENDES, C.C., ARAÚJO-JÚNIOR, I.T. de, FERNANDES, A.P., LYRA, D.M., OLIVEIRA, G.L. de, OLIVEIRA, C.G. de \& BARBOSA, N.B. da S. 2012. A Paraíba no Contexto Nacional Regional e Interno. IPEA, Brasilia, DF.

MONTES-FONTALVO, J.M., CANO-COBOS, Y., PEREZ, L. \& SAADE, E. 2021. Progomphus dorsopallidus. The IUCN Red List of Threatened Species 2021: e.T166492253A166693730.

NAVÁS, L. 1916. Neuropteres sudamericanos. Tercera serie. Neuropteres del Brasil recogidos por el R.P. Joaquin da Silva Tavares S.J. Broteria, Ser. zool. 14(1):14-35.

NOBRE, C.E. \& CARVALHO, A.L. 2014. Odonata of Itatira, a Brazilian semiarid area in the state of Ceará. Int. J. Odonatol. 17(2-3): 73-80.

NOBRE, C.E.B. 2016. Erythrodiplax leticia: Description of the female and updated geographic distribution (Odonata: Libellulidae). Zootaxa 4067(4):469-472.

OLAYA, M. 2019. Odonatos en Latinoamérica: la riqueza de nuestra región. Hetaerina 1(2):4-5.

PAULSON, D. \& SCHORR, M. 2020. World Odonata List. https://www. pugetsound.edu/academics/academic-resources/slater-museum/biodiversityresources/dragonflies/world-odonata-list2/ (last access on 15/01/2021).

PINTO, Â.P. 2013. Análise cladística de Sympetrinae Tillyard, 1917 com ênfase no grupo de armadura femoral especializada: os gêneros de "Erythemismorpha" (Insecta: Odonata: Libellulidae). Ph.D. thesis, Universidade de São Paulo, São Paulo.

PINTO, Â.P. 2021. Odonata in Catálogo Taxonômico da Fauna do Brasil. PNUD. http://fauna.jbrj.gov.br/fauna/listaBrasil/ConsultaPublicaUC/ BemVindoConsultaPublicaConsultar.do?invalidatePageControlCounter $=1 \& 1$ ingua $=$ pt\&jsonRank $=\&$ rankTaxon $=32767 \&$ nomeTaxon $=\&$ autor $=\&$ nomeVer naculo $=\&$ nomeCompleto $=$ Odonata + Fabricius $\% 2 C+1793 \&$ formaVida $=Q U A$ LQUER\&substrato $=$ QUALQUER\&ocorrencia $=$ OCORRE\&regiao $=$ QUALQ UER\&estado $=\mathrm{PB} \&$ endemismo $=$ TODOS\&origem $=$ TODOS\&mostrarAte $=\mathrm{S}$ UB_ESPECIE\&opcoesBusca=NOME_ACEITO (last access on 14/01/2021).

PINTO, Â.P. \& CARVALHO, A.L. 2012. Taxonomic and distributional notes on Telebasis Selys, 1865, with a redescription of T. pallida Machado, 2010, and an evaluation of the T. racenisi Bick \& Bick, 1995 "complex" of species (Odonata, Coenagrionidae). Mitteilungen aus dem Museum fur Naturkd. Berlin - Dtsch. Entomol. Zeitschrift 59(2):189-200.

REZENDE, C.L., SCARANO, F.R., ASSAD, E.D., JOLY, C.A., METZGER, J.P., STRASSBURG, B.B.N., TABARELLI, M., FONSECA, G.A. \& MITTERMEIER, R.A. 2018. From hotspot to hopespot: An opportunity for the Brazilian Atlantic Forest. Perspect. Ecol. Conserv. 16(4):208-214.

RIEK, E.F. \& KUKALOVÁ-PECK, J. 1984. A new interpretation of dragonfly wing venation based upon Early Upper Carboniferous fossils from Argentina (Insecta: Odonatoidea) and basic character states in pterygote wings. Can. J. Zool. 62(6):1150-1166. 
RODRIGUES, M.E., MOURA, E.B., KOROIVA, R., BORGES, A.C.P. \& ROQUE, F. de O. 2018. Survey of Dragonflies (Odonata) in Palm Swamps of Cerrado Hotspot. Entomol. News 128(1):24-38.

SANTOS, J.C., VILELA, D.S., ALMEIDA, W.R. de, SANTOS, B. dos, SANTOS, A.E. dos, BEZERRA, L.M. de M., SANTOS, L. dos, NETO, A.M. dos S., VENÂNCIO, H. \& CARNEIRO, M.A.A. 2020. A rapid survey of dragonflies and damselflies (Insecta: Odonata) reveals 29 new records to Sergipe State, Brazil. Hetaerina 2(2):29-34.

SANTOS, N. 1946. Cendra cearana Navas, 1916, sinônimo de Macrothemis griseofrons Calvert, 1909. Summa Bras. Biol. 1:1-7.

SILVA, J.I.A.O., BARBOSA, E.S.L., SILVA, A.G.F. da \& NUNES, G.H.F. 2017. Unidades de conservação no semiárido brasileiro: Estudo da gestão desses espaços preservados. Reun. Rev. Adm. Contab. e Sustentabilidade $7(2): 48-66$

SILVA, J.M.C. da \& BARBOSA, L.C.F. 2017. Impact of Human Activities on the Caatinga. In Silva J.M.C., Leal I.R., Tabarelli M. (Eds.) Caatinga. Springer, Cham, p.359-368.

ST. QUENTIN, W.V.D. 1973. Die Gomphidenfauna Südamerikas (Ordn. : Odonata). Ann. des Naturhistorischen Museums Wien. 77:335-363.
TAKIYA, D., SANTOS, A.P., PINTO, Â., HENRIQUES-OLIVEIRA, A.L., CARVALHO, A., SAMPAIO, B., CLARKSON, B., MOREIRA, F., AVELINO-CAPISTRANO, F., GONÇALVES, I., CORDEIRO, I., CÂMARA, J., BARBOSA, J., DE SOUZA, W.R. \& RAFAEL, J.A. 2016. Aquatic Insects from the Caatinga: checklists and diversity assessments of Ubajara (Ceará State) and Sete Cidades (Piauí State) National Parks, Northeastern Brazil. Biodivers. Data J. 4:e8354.

VILELA, D.S. 2021. Libélulas de Minas Gerais. http://libelulasdemg.com.br/ especies.php (last access on 06/04/2021).

VILELA, D. \& GUILLERMO-FERREIRA, R. 2021. Macrothemis griseofrons. The IUCN Red List of Threatened Species 2021:e.T166494203A166693855.

VILELA, D.S., KOROIVA, R., TOSTA, T.H.A., NOVAES, M.C. \& GUILLERMOFERREIRA, R. 2020. Dragonflies and damselflies from the West of Minas Gerais, Brazil: checklist and new records. Biota Neotrop. 20(1):e20190851. https://doi. org/10.1590/1676-0611-bn-2019-0851 (last access on 20/04/2021).

Received: 26/01/2021

Revised: 26/04/2021

Accepted: 04/05/2021

Published online: 04/06/2021 